\title{
「健康食品」の広告の問題点
}

\author{
白神 誠
}

\section{Problems with Advertisements for Health Foods}

\author{
Makoto Shiragami \\ Depatment of Pharmaceutical Science, Teikyo Heisei University; \\ 4-21-2 Nakano, Nakano-ku, Tokyo 164-8530, Japan.
}

(Received July 12, 2018)

\begin{abstract}
We have been studying the way advertisements for medicines have been monitored by the Health, Labour and Welfare Sciences Research Grants. In the last fiscal year, we identified products that were being advertised to general consumers, such as OTC drugs and designated quasi-drugs, and made recommendations to the Ministry of Health, Labour and Welfare on the methods of advertisement. Members of our research group, including physicians, pharmacists, and consumers, pointed out that advertisements for so-called health foods and foods with functional claims were much more unregulated than those for drugs, including OTC drugs. Thus, this fiscal year, we decided to focus on health foods. Advertisements for health foods are regulated by the Health Promotion Act and the Act against Unjustifiable Premiums and Misleading Representations; moreover, in many cases, cautions are issued by the Consumer Affairs Agency or prefectures. Several studies also reported health damage in patients who, because of their belief in advertisements, intentionally discontinued treatment or missed the opportunity to receive appropriate medical treatment. Here, we report inappropriate advertisements for health foods that may cause health hazards.
\end{abstract}

Key words — health food; advertisement; health hazard

\section{1. はじめに}

厚生労働科学研究費補助金により，医薬品等の広 告監視の適正化を図るための検討を行つている．昨 年度は一般用医薬品や指定医薬部外品など一般消費 者に向けた広告が行われている製品を取り上げ，そ の広告のあり方について提言を行った．その検討に 際して，医師，薬剤師，消費者から，一般用医薬品 等の広告規制に比較して, いわゆる健康食品や機能 性表示食品の広告があまりにも野放図であるとの指 摘がなされたことから，今年度は健康食品を検討の 対象に加えることとした，健康食品の広告は，健康 増進法や景品表示法による規制を受け，消費者庁や 都道府県から指導を受ける例も少なくない。中に は，広告を信じて，適切な医療を受ける機会を逸し たり，治療を中断したりして健康被害を生じた例も

帝京平成大学薬学部 ( $164-8530$ 東京都中野区中野 421-2)

e-mail: m.shiragami@thu.ac.jp

本総説は, 日本薬学会第 138 年会シンポジウムS56 で

発表した内容を中心に記述したものである.
報告されている。このように健康被害を生じかねな い健康食品の不適切な広告の実態を報告する.

\section{2. 不適切な健康食品の広告がもたらす健康被害}

2-1. 事故情報データバンクに登録された健康被 害の事例 消費者庁と独立行政法人国民生活セン ターが連携して実施している「事故情報データバン クシステム」1)で，「健康食品」かつ「事故情報」の キーワードで検索すると 2009 年 4 月-2018 年 3 月 に登録されたものは 7763 件であった。事業が開始 された当初は 280 件前後の登録件数であったが, 2011 年度に 586 件と前年の 2 倍以上となり，2015 年度には 900 件近く, 2016 年度には 2000 件近くに 増加している. 報告に基づく傷病内容では消化器障 害が 3397 件 (44\%)，皮膚障害が 2300 件（30\%） とこれら 2 つで全体の 4 分の 3 を占めている。 ま た，傷病の程度については報告のあつた 5624 件の うち 3975 件（71\%）は医者にかかっておらず，こ れを含め 4924 件 $(88 \%)$ は 1 週間以内の治療で済 んでいる。一方で治療に 1 力月以上要したと報告し ているものが 272 件 $(5 \%)$ あり，死亡も 17 件 
（0.3\%）報告されていた.

これらの健康被害が，健康食品の有効性に関する 広告を信じて消費者が摂取した結果生じたのかどう かは調査されていない。そこで 2005 年度に登録さ れた健康食品に関する事故情報のうち直近 500 件に ついて，「事故情報データバンクシステム」に添付 されている「事故情報詳細」を 1 件 1 件確認し，健 康食品の摂取のきつかけが当該健康食品の有効性に 関する広告にあるのかどうかを検討した．事故情報 詳細には，何を通じて当該健康食品を入手したかが 記載されているものがある。「インターネット」, 「スマホ」,「SNS」,「折り込み広告」,「テレビショッ ピング」,「テレビ広告」,「通販」等により購入した とする者は，対象とした 500 件中 300 件あり，少な くともこれらについては，それを販売する企業によ る広告を見て購入するに至ったと推測することがで きる. 以下に具体的な事例を紹介する.

事例 1 アレルギー症状のある夫が乳酸菌の健康 食品を約 1 力月飲用したところ, 全身に発疹が出て 通院している．注意表記を明確にすべきだ（60歳 代).

乳酸菌を含有する飲料を販売しているある大手企 業のホームページでは，「アレルギー症状を改善す る」「多くの方がお悩みのアレルギー症状に有効な 成分と指定，今注目を集めている…「アトピー性 皮膚炎, 通年性アレルギー性鼻炎, 花粉症の症状を 改善するその働きについて，詳しく見ていきましょ う」との記述がある。その企業の製品が健康被害の 原因となった製品であったかどうかは不明である が，他社でも同じような広告が行われており広告に 影響されて使用を始めた可能性は否定できない。

事例 2 スマホでダイエット食品を購入し服用後 体調不良になり医師に服用を止められた (30 歳代).

事故情報データバンクに登録された事例でダイ エット目的に多くの人が購入している「スムージー」 を販売しているある企業のホームページでは，「“楽 に瘦せる”で話題沸騰！?」「みんなが気になる」な どの記述がある。その企業の製品が健康被害の原因 となった製品であったかどうかは不明であるが，他 社でも同じような広告が行われており広告に影響さ れて使用を始めた可能性は否定できない.

事例 3 腎臓の特効薬といわれて購入した健康食 品を服用していたらタンパクの数值が悪化した（70
歳代)

腎臓によいとする健康食品を販売しているある企 業のホームページでは，「1.0を超えた $\cdots$, もやも や‥」「かん腎なときはコレ」などの記述がある. その企業の製品が健康被害の原因となった製品で あったかどうかは不明であるが，他社でも同じよう な広告が行われており広告に影響されて使用を始め た可能性は否定できない.

事例 4 テレビショッピングで血圧を下げるサプ リメントを購入し，昨日服用．夜間に大量に血便が 出た。 今は血便は止まったが腹痛がある(年齢不明).

いわし由来のペプチドを含有する特定保健用食品 を販売するある大手企業のホームページでは，「血 圧が高めの方に $130 \mathrm{mmHg}$ を超えたら」の記述と ともに人での試験結果を掲載している，その企業の 製品が健康被害の原因となつた製品であったかどう かは不明であるが，他社でも同じような広告が行わ れており広告に影響されて使用を始めた可能性は否 定できない.

事例 5 通信販売で女性らしい体型になるという 健康食品を定期購入し，初回分を飲んでいると大量 の不正出血が起こつた。この健康食品が原因とは思 わずに飲夕続けていたが，病院に行くと子宮内膜が 厚くなっているとのことで, 健康食品との因果関係 は分からないが飲まないよう言われた（30 歳代）。

事例 6 高校生の娘がモデルのブログを見て，バ ストアップやダイエットのサプリメントに興味を持 ち，定期購入で契約，サイトには 5 回目以降は連絡 ひとつで休止でき，90日間全額返金保証と書かれ ているが，契約日から 5 力月以上経過している．生 理が 2 力月も遅れていて心配 (10 歳代).

これらの事例を背景に，国民生活センターから， 「美容を目的とした『プエラリア・ミリフィカ』を 含む健康食品一若い女性に危害が多発！安易な摂 取は控えましょう一」との警告が出されている。プ エラリア・ミリフィカを含有する製品を販売してい るある企業のホームページでは，「女性医師たちも 続々購入」「ぐっとふっくら」「ずっと女性らしく」 などの記述がある．その企業の製品が健康被害の原 因となった製品であったかどうかは不明であるが, 他社でも同じような広告が行われており広告に影響 されて使用を始めた可能性は否定できない，

2-2. 健康食品の広告の規制健康食品の広告 
を規制する法律には，医薬品医療機器等法，健康増 進法, 景品表示法がある。医薬品医療機器等法で は，医薬品の定義（人又は動物の身体の構造又は機 能に影響を及ぼすことが目的とされている物又は人 又は動物の疾病の診断，治療又は予防に使用される ことが目的とされている物）に該当すれば無許可医 薬品の製造・販売として処分の対象となり得る．健 康増進法では，健康保持増進効果等について著しく 事実に相違する又は著しく人を誤認させる広告を禁 止しており，また景品表示法では，実際のものより も著しく優良であると示す等の広告を禁止している.

健康食品の所管は消費者庁であるが，消費者庁で はインターネットにおける健康食品等の虚偽誇大表 示を監視しており，健康増進法あるいは景品表示法 に基づき必要に応じ改善要請を行っている，2017 年 10 月-12 月の間に健康増進法に基づき改善要請 を行った事例として以下のものがあった.

事例 1 生鮮食品（農産物）４商品で，生活習慣 病の予防，貧血予防，便秘解消などの効果を有する こと等を標ぼうする表示を行っていた.

事例 2 加工食品（農産加工品, 畜産加工品, 水 産加工品等） 8 商品で, 活性酸素の働きの抑制, が んや動脈硬化の予防，花粉症，エイジングケアに効 果を有すること等を標ぼうする表示を行っていた.

事例 3 飲料等（茶，コーヒー及びココア調製 品, 飲料, 酒類) 8 製品で, 心臓病・動脈硬化の予 防，抗がん剂としての働き，高血圧・糖尿病の予防 などの効果を有すること等を標ぼうする表示あるい は粘膜の保護，免疫力アップにより，風邪やインフ ルエンザ，花粉症に効果を有すること等を標ぼうす る表示を行っていた。

事例 4 いわゆる健康食品（カプセル，錠剂，顆 粒状等） 72 商品で, 脂肪燃焼, 新陳代謝の向上, 老廃物の除去の効果を有すること等を標ぼうする表 示あるいは女性ホルモンの活性化に働きかけ，美白 美肌，更年期障害の軽減，高血圧や動脈硬化の予防 等に効果を有することを標ぼうする表示を行ってい た.

また，景品表示法による処分の対象となつた健康 食品としては以下の事例があった.

事例 1 ココナッツオイルの製品で，あたかも， 対象商品を摂取することにより，認知症，がん等の 各種疾病を予防する効果等が期待できるかのように
示す表示を行つていた（2016 年 3 月 31 日）.

事例 2 かつお節オリゴペプチドの製品で，当該 商品が特定保健用食品として消費者庁長官の許可の 要件を満たしたものであるかのように示す表示を 行っていた（2017 年 6 月 7 日）.

事例 3 葛の葉由来イソフラボンの製品で，あた かも，対象商品を摂取するだけで，誰でも容易に， 内臓脂肪（及び皮下脂肪）の減少による，外見上， 身体の変化を認識できるまでの腹部の瘦身効果が得 られるかのように示す表示を行っていた（2018 年 1 月 19 日).

事例 4 プエラリアの製品で，商品を㩒取するだ けで, 豊胸効果が得られるとともに瘦身効果が得ら れるかのように示す表示を行っていた（2018 年 3 月 23 日).

\section{3. がんと健康食品}

消費者はインターネットを通じて健康食品につい ての情報を収集することが多いのではないかと考 え，想定される消費者の情報収集経路をたどること により健康食品の有効性に関する広告の実態把握を 行った。広告でがんに対する効果を謳うことは，他 の疾患のケースとは異なり明らかに医薬品の定義に 該当することになる。そこで，マスコミ等でがんへ の効果が話題になることの多い成分について，「成 分十癌」のキーワードで Google の検索エンジンを 用いて検索し，上位に掲載されたものについて検討 を行った.

マスコミ等でがんへの効果が話題になることの多 い成分として，「霊芝」，「フコイダン」，「プロポリ ス」を取り上げた。これらの製品を扱っている企業 のホームページでは，おそらく医薬品医療機器等法 を意識しているのであろうか直接がんに対する効果 を謳つているものは「霊芝」を除きほとんどない。 「霊芝」では多くの企業がホームページでがんに対 する効果を謳っている，これらの企業は「広告」と する（Google 等に費用を支払う）ことによって， 絶えず検索結果の上位に来るようにしている.

検索結果の上位には，個人のブログや研究会のよ うなものが上がってきて，がんに対する効果をデー 夕を交えながら自由に記述している。一見公正なサ イトのように見えるが，研究会の中には実質的企業 がスポンサーとなっているものもあり，また，ブロ グの中には，いわゆるアフィリエイト広告と思われ 
るものも見受けられる，たとえ，製品を扱つている 企業のホームページに直接がんに効果がある旨の記 述がなくても，インターネットに検索をかけた消費 者はがんに効果があると認識するように仕向けられ ている。

\section{4. 健康食品に関する消費者 web 調査}

消費者における健康食品による健康被害の実態と 健康食品の広告に対する認識等を明らかにするため 消費者を対象とした web 調查を実施した。Web 調 査は，インターネット調査会社に登録されたモニ ターのうち現在健康食品を利用している人を対象に 2018 年 3 月に実施した．回答者の年代を 20 代以下， 30 代，40 代，50 代，60 代以上とし各年代男女それ ぞれ 100 名，計 1000 名の回答を収集することと し，予定の人数が集まつた年代についてはその段階 で回答募集を終了した。

（1）「健康食品」として思い浮かべるもの

「健康食品」と言つたときにそれぞれの消費者に よって思い浮かべるものに違いがあることが予想さ れることから行った質問である．最も多くの人が健 康食品と考えたのは「健康によい成分を入れたカプ セル，錠剤，粉末，液体（いわゆるサプリメント)」 で $74.1 \%$ ，ついで「特定保健用食品（トクホ）」が 61.6\%で，これら以外のものはすべて $50 \%$ 以下で あった．以後の質問に対する回答は，回答者が健康 食品と考えているものについての回答であることに 留意する必要がある.

（2）現在利用中の健康食品の種類数

現在利用中の健康食品が 1 種類のみの人は 330 人 $(33.0 \%)$ で, 残りの 670 人 $(67.0 \%)$ は複数の健 康食品を利用している，回答の中での最大は 25 種 類で，10 種類以上利用している人がこれを含め 24 人 (2.4\%) いた（Fig. 1).

（3）健康食品についての説明

健康食品に関するいくつかの説明について，正し いと思うかどうかを尋ねた。

(1)健康食品は，病気を予防したり治したりできる と表示することはできない

正しい（正解）と回答した人が $78.9 \%$, 正しく ないと回答した人が $6.6 \%$ と多くの人が理解してい た。特に 60 代以上では $87.5 \%$ が正しいと回答して いる．それにもかかわらず多くの人がこれらの効果 を期待して健康食品を利用していることとのギャッ

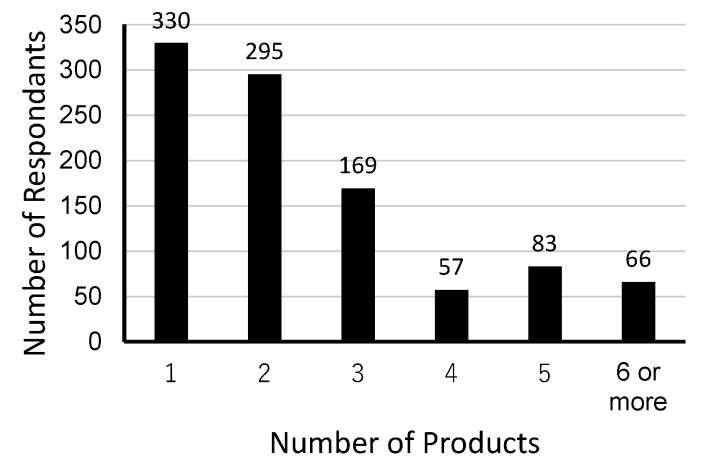

Fig. 1. Number of Health Food Products Currently in Use

プについて検討する必要があろう（Fig. 2)。

(2)健康食品で健康被害が生じたとき被害者を救済 する国の制度がある

正しいと回答した人が $29.4 \%$ ，正しくない（正 解）と回答した人が $22.5 \%$ とほぼ拮抗していた.

しかし，わからないと回答した人が $48.1 \%$ と半数 近くにのぼっている (Fig. 3).

（4）健康食品を利用して体調を崩した経験

これまでに健康食品を利用して体調を崩したと回 答した人が $6.1 \%$ あった（Fig. 4)．症状としては消 化器症状が 34 件 $(55.7 \%)$ と半数以上を占め, つ いで皮膚症状が 12 件（19.7\%）となっている。体 調を崩したときに 31 人 $(50.8 \%)$ は，「特に何もし なかった」と回答しており，多くは重大な健康被害 でなかったと思われる。しかし，医師に相談した人 が 11 人 $(18.0 \%)$ おり，中には肝機能障害や出血 が止まらないなどの症状の人もいた.

（5）健康食品を 2 力月ほど利用して満足する効 果が得られなかった場合の対応

健康食品を 2 力月ほど利用して満足する効果が得 られなかった場合に，「利用するのをやめる」と回 答した人が $44.2 \%$ ，「がまんして，もう少し利用す る」と回答した人が $51.1 \%$ ，「抏取する量を増やす」 と回答した人が $4.7 \%$ であった「利用するのをや める」と回答した人は女性に比べて男性の方がわず かに多かった（Fig. 5)。年代別にみると，男性の 20 代以下， 30 代及び女性の 20 代以下では，「摂取 する量を増やす」と回答した人が $9.0 \%$ おり，女性 の 30 代でも $7.0 \%$ と年代の若い人で「摂取する量 を増やす」と回答した人が多くみられ，健康食品に ついては，摂取すべき量を守らないことによる健康 被害の発生が指摘されており留意する必要がある. 


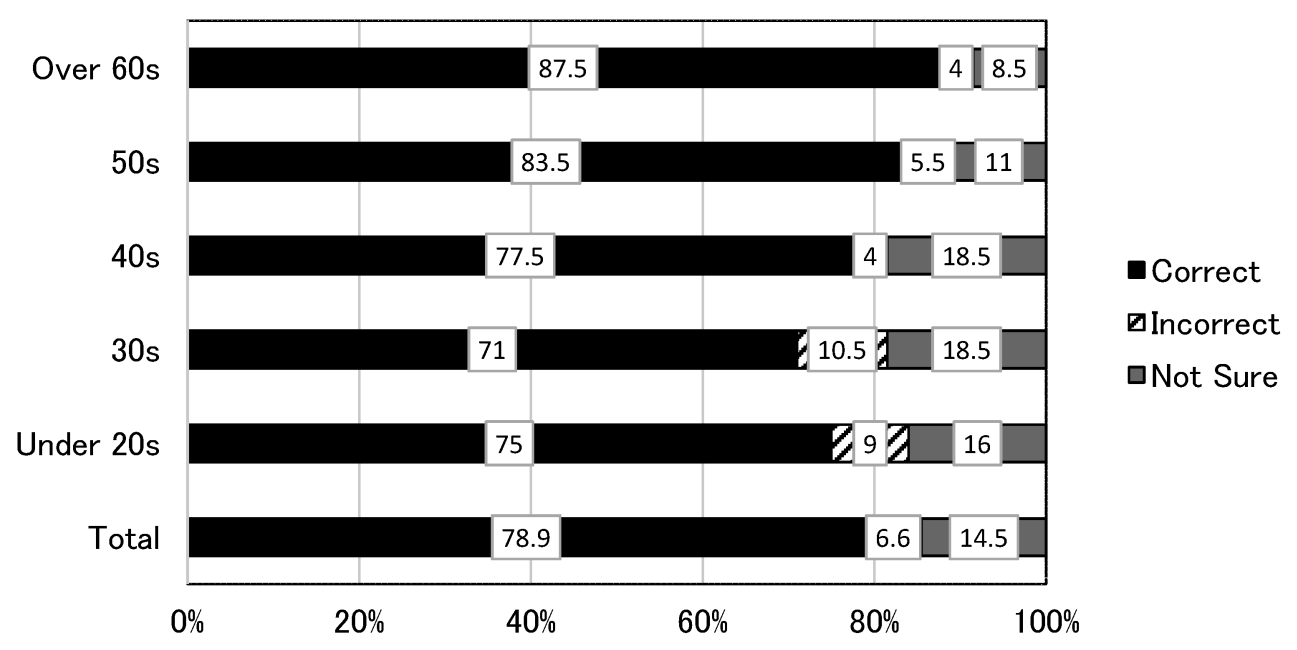

Fig. 2. Is It Correct That Health Foods Should Not Claim to Cure or Prevent Disease?

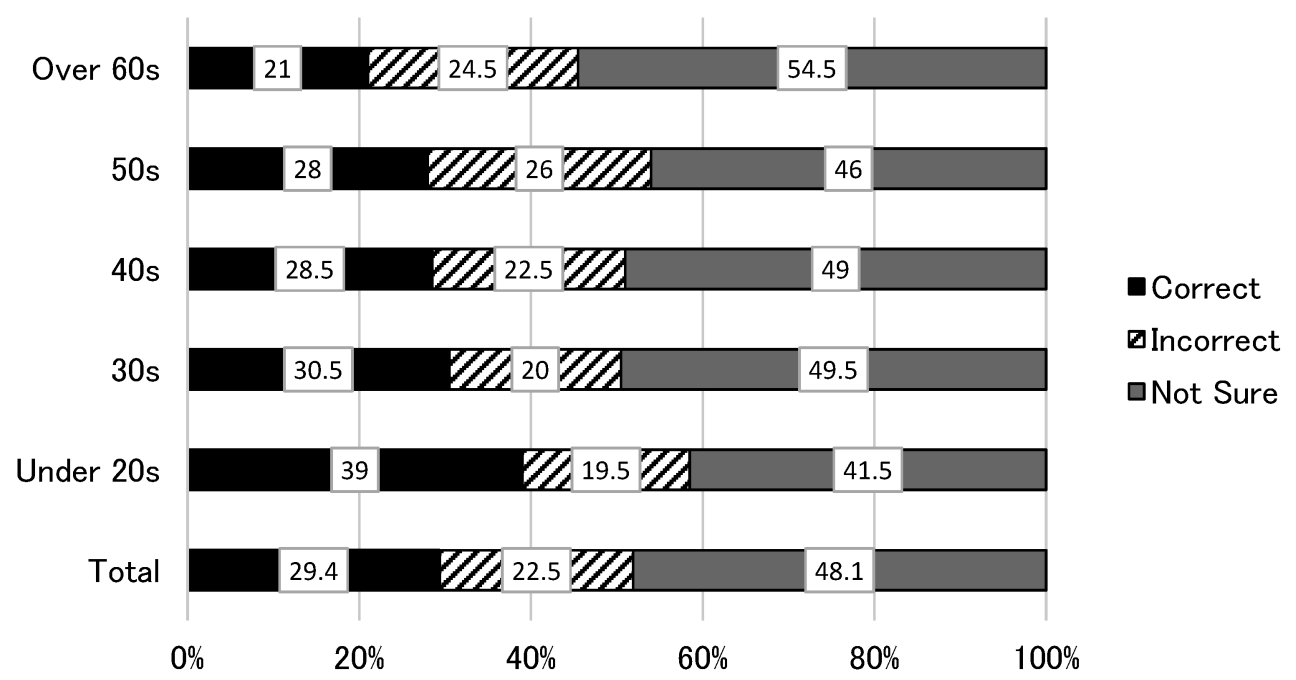

Fig. 3. Is It Correct That There Is a National System to Provide Relief to Consumers from the Adverse Health Effects Due to Health Foods?

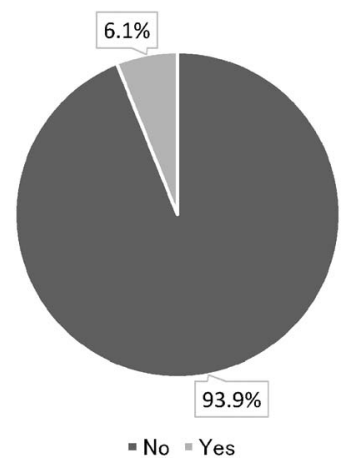

Fig. 4. Experiences of Loss in Physical Condition Due to Health Food Use

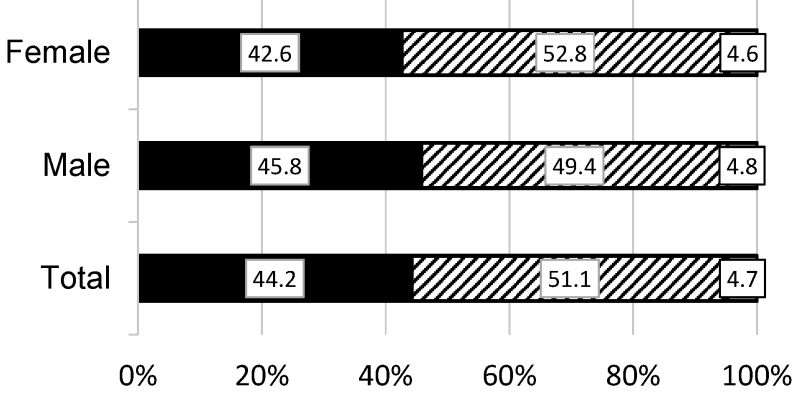

$\square$ Stop using it $\boldsymbol{\square}$ Use it a little more $\boldsymbol{\square}$ Increase intake

Fig. 5. What to Do if Satisfactory Results Cannot Be Obtained after Consuming Health Foods for Approximately Two Months? 


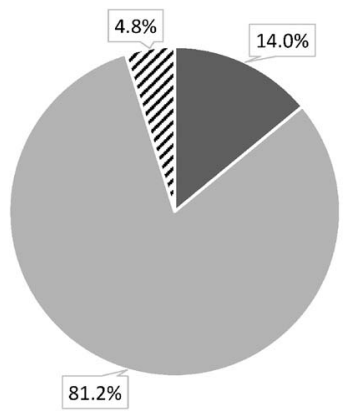

- I will tell even if not heard

I I will tell if asked

I will not tell even

if asked

Fig. 6. Do You Tell Your Doctor about Your Health Food Use?

（6）医師に健康食品の利用を伝えるか

医師に「聞かれなくとも健康食品を利用している ことを伝える」と回答した人は 140 人 $(14.0 \%)$, 「聞かれても話さないと思う」と回答した人は 48 人 (4.8\%) で，大部分の人 $(81.2 \%)$ は「聞かれれば 話すと思う」と回答していた（Fig. 6).

（7）現在利用している健康食品を選んだ決め手

現在利用している健康食品を選んだ決め手につい て選択肢の中から 3 つ以内で選んでもらつた。最も

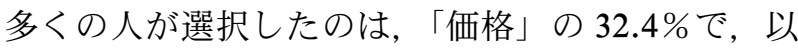
下「家族・知人の勧め」 $28.8 \%$ ，「広告にあった品 質の保証」 $22.0 \%$ ，「広告にあった利用した人の経 験談」 $16.8 \%$ の順であつた（Fig. 7).
（8）広告への反応

健康食品の広告でしばしば見かける内容につい て, 健康食品を選ぶ際の判断にごの程度の影響を与 えるかを 0 から 100 の間のスコアで尋ねた（以下の (1)から (4))。また，健康食品の広告でよく見かける 文言についてどの程度製品の信頼につながるかにつ いて 0 から 100 の間のスコアで尋ねた（以下の(5)か ら(7)) (Table 1).

(1)健康食品を利用した人の経験談

影響の度合いの全体の平均は 51.8 で，男女で大 きな差はみられない，年代別にみると，男の 20 代 以下が 58.6 と最も高く，ついで女の 20 代以下の 57.4 が続いている。 一方最も低いのは男の 50 代の 46.8 で，ついで女の 60 代以上の 48.4 となってい る. 男女とも若い人ほど影響を受けると回答する傾 向がみられた。

(2)利用者のアンケート結果

影響の度合いの全体の平均は 49.1 で，男女で大 きな差はみられない，年代別にみると，女の 20 代 以下が 56.3 と最も高く, ついで男の 20 代以下の 55.0 が続いている. 一方最も低いのは女の 60 代以 上の 43.7 で，ついで男の 50 代の 44.0 となってい る. 男女とも若い人ほど影響を受けると回答する傾 向がみられた。

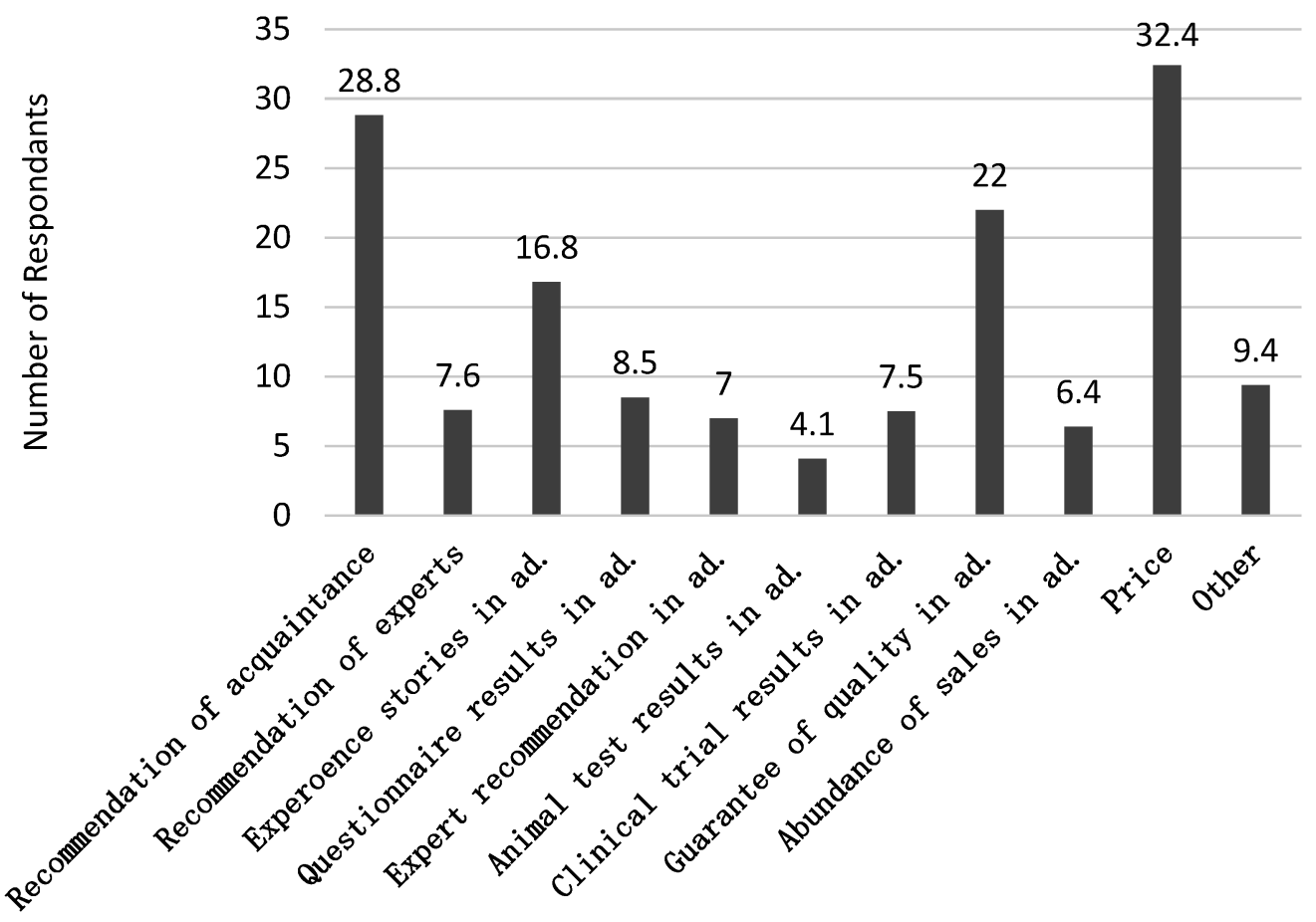

Fig. 7. Deciding to Use Health Foods Currently in Use 
Table 1. Responses to Advertisements

\begin{tabular}{l|c|c|c|c|c|c|c}
\hline \hline & $\begin{array}{c}\text { Experience } \\
\text { stories }\end{array}$ & $\begin{array}{c}\text { Questionnaire } \\
\text { results }\end{array}$ & $\begin{array}{c}\text { Expert } \\
\text { recommendation }\end{array}$ & $\begin{array}{c}\text { Sales } \\
\text { ranking }\end{array}$ & $\begin{array}{c}\text { Natural } \\
\text { ingredients }\end{array}$ & $\begin{array}{c}\text { Domestic } \\
\text { products }\end{array}$ & $\begin{array}{c}\text { Clinically } \\
\text { tested }\end{array}$ \\
\hline Under 20s, male & 58.6 & 55.0 & 57.2 & 54.1 & 58.3 & 58.3 & 61.0 \\
\hline 30s, male & 52.8 & 50.5 & 58.0 & 50.1 & 58.4 & 56.9 & 56.1 \\
\hline 40s, male & 50.0 & 47.2 & 56.5 & 45.2 & 60.7 & 61.6 & 57.3 \\
\hline 50s, male & 46.8 & 44.0 & 53.7 & 38.4 & 53.2 & 54.3 & 57.0 \\
\hline Over 60s, male & 49.3 & 47.0 & 60.0 & 46.4 & 58.8 & 58.9 & 60.2 \\
\hline Total, male & 51.5 & 48.7 & 57.1 & 46.8 & 57.9 & 58.0 & 58.3 \\
\hline Under 20s, female & 57.4 & 56.3 & 60.0 & 53.5 & 54.5 & 60.7 & 60.4 \\
\hline 30s, female & 52.7 & 49.8 & 56.8 & 46.3 & 56.8 & 60.7 & 60.6 \\
\hline 40s, female & 49.8 & 48.2 & 57.7 & 44.2 & 57.2 & 61.3 & 59.5 \\
\hline 50s, female & 52.1 & 49.0 & 56.2 & 43.2 & 58.2 & 63.4 & 62.6 \\
\hline Over 60s, female & 48.4 & 43.7 & 57.7 & 41.7 & 53.8 & 58.0 & 60.8 \\
\hline Total, female & 52.1 & 49.4 & 57.7 & 45.8 & 56.1 & 60.8 & 60.8 \\
\hline Total & 51.8 & 49.1 & 57.4 & 46.3 & 57.0 & 59.4 & 59.6 \\
\hline
\end{tabular}

\section{(3)医師などの専門家の推奨}

影響の度合いの全体の平均は 57.4 で，男女で大 きな差はみられない。年代別にみると，男の 60 代 以上と女の 20 代以下とがともに 60.0 と最も高く なっている。一方最も低いのは男の 50 代の 53.7 で，ついで女の 50 代の 56.2 となっている.

(4)売り上げのランキング

影響の度合いの全体の平均は 46.3 で，男女で大 きな差はみられない。年代別にみると，男の 20 代 以下が 54.1 と最も高く，ついで女の 20 代以下の 53.5 が続いている。 一方最も低いのは男の 50 代の 38.4 で, ついで女の 60 代以上の 41.7 となっている.

(5)天然の成分とか自然の素材を使用している製品 は安心できる

全体の平均は 57.0 と比較的高かったが，男女で 差がみられ，男が 57.9，女が 56.1 と，男の方が 1.8 ポイント高い. 年代別にみると, 男の 40 代が 60.7 と最も高く，ついで男の 60 代以上の 58.8 が続 いている. 一方最も低いのは男の 50 代の 53.2 で, ついで女の 60 代以上の 53.8 となっている.

(6)国産の成分を使用している製品は安心できる

全体の平均は 59.4 と比較的高かったが，男女で 差がみられ，男が 58.0，女が 60.8 と，女の方が 2.8 ポイント高い. 年代別にみると, 女の 50 代が 63.4 と最も高く，ついで，男の 40 代の 61.6 が続い
ている，一方最も低いのは男の 50 代の 54.3 で，つ いで男の 30 代の 56.9 となっている.

（7)「臨床試験済み」とある製品は効果や安全性が 高い

全体の平均は 59.6 と比較的高かったが，男女で 差がみられ，男が 58.3 ，女が 60.8 と，女の方が 2.5 ポイント高い. 年代別にみると，女の 50 代が 62.6 と最も高く，ついで男の 20 代以下の 61.0 が続 いている. 一方最も低いのは男の 30 代の 56.1 で, ついで男の 50 代の 57.0 となっている.

\section{5. まとめ}

消費者は，健康食品をなんらかの効果を期待して 摂取している．Web 調査によれば，その健康食品 を選んだ決め手は知人や専門家に勧められたケース を除けば，ほとんどが企業による広告である．企業 が行う健康食品の有効性に関する広告を信じてその 健康食品を摂取し，一部で健康被害を生じていると すれば，企業の行う広告について厳しく監視する必 要があることは当然のことであろう。健康食品の広 告は，景品表示法と健康増進法により規制される が，いずれも健康保持増進効果を表示することその ものを禁止しているわけではない。そのために健康 食品の広告では, 医薬品の広告では好ましくないと されている，医師等の推奨や，使用者の経験談，利 用者のアンケート結果などを駆使して消費者に利用 
を促している. 企業の健康食品の有効性に関する広 告に誘発されてその健康食品を使用し, 結果として 健康被害を生じている事例があるのであれば，医薬 品医療機器等法に基づき無許可医薬品として取り締 まることも考慮すべきではないかと考える.

謝辞本研究は, 厚生労働科学研究費補助金に より行つたものである.

\section{利益相反＼cjkstart開示すべき利益相反はない.}

\section{REFERENCE}

1) Consumer Accident Information Databank: 〈http://www.jikojoho.go.jp/ai_national/〉, cited 20 March, 2018. 